\title{
DE LA RAZON RECTORA A UNA RACIONALIDAD GESTORA
}

Amancio Gutiérrez Martinez.

Tras las guerras de religión que ensangrentan Europa en el siglo xvil, la religión, que antes unia, ahora separa. Europa pierde el sustrato cultural sobre el que asentaba su pretendida identidad y con el que legitimaba el viejo orden social. Ahora necesita pensarse de una manera más acorde con el nuevo orden internacional, surgido de la "guerra de los Treinta Ahos", y en consonancia con los valores de la nueva clase social rectora que está emergiendo, la burguesía, propulsora del nuevo orden social y económico. La razón cartesiana, al mismo tiempo que llena el vacio que la dejado la religión, legitima el orden social burgués que emerge.

Si cl hombre curopeo se ha equivocado al depositar su confianza en la religión, no puede correr el mismo riesgo, ya que en ello le va la convivencia social y política. La nueva razón que será garantia de no volver a equivocarse en el futuro, admitirá sólo lo que sea cierto y evidente como la mejor manera de no caer en el error. Al llenar el vacio dejado por la religión, la razón se conforma según su patrón y adquiere sus mismas características: a) no es espontánea: no se configura a sí misma y sufre tantas constricciones externas que incluso deja de ser ella misma para lacerse mecánica, y al instalarse en el nivel formal del pensamiento, propio de las ciencias formales, se convertirá, como ellas, en algo meramente instrumental. Es, pues, una razón mutilada, aunque el "engranaje deductivo" siga su propio curso de una manera inflexible y la dote de una aparente autonomia. b) la evidencia como criterio de certeza exige un "asentimiento ciego", acompañado de una total "ausencia de crítica", y al eliminar la diferencia, la divergencia y la disidencia, destruye de raiz todo "pluralismo" político, ideológico y cultural. Será una razón que legitime el absolutismo de Estado. c) la racionalidad le viene dada al sujeto; no surge del libre ejercicio de la propia razón. Tanto el ejercicio de la razón como los contenidos obtenidos del ejercicio de la misma, no son el resultado de una acción comunitaria, ejercida de una menera solidaria y compartida por todos los miembros de la sociedad. Ello conlleva la consiguiente negación de la sociedad como sujeto capaz de trazar su propio destino y ser el agente conductor de su curso. d) la rigidez mecánica impide realizar procesos de retroalimentación y no se acomoda a la circunstancia histórica. Es más, con el pretexto de trascenderla, no se incardina en el devenir de la conciencia social. e) constriñe lo afectivo y pasional. f) es presa fácil de la ideología. La razón cartesiana deviene pronto en ideología de la clase dominante como instancia que legitima el orden social burgués.

Esta razón externa y rectora sufre un progresivo deterioro. El propio curso fillosótico o el devenir de la conciencia social descubren de inmediato sus condicionantes y limites: no se adapta al medio cultural ni evoluciona con sl, porque su conocimiento, limitado internamente por su carácter mecánico, carece de la necesaria llexibilidad para incardinarse en la conciencia social y en su devenir histórico. Cuando la razón queda inserta en la realidad social como factor que la conforma y dirige su curso, hace conscientes los mecanismos sociales: infrnestructura, ideologia, intereses, etc., pierde todo punto de vista absolutizador (Historicismo) y el puesto más alto en la escala de jerarquizaciones (Vitalismo), ${ }^{1}$ descubre los limites y el alcance de todo

1 Martínez Juan M.: La flosofiu de las Ciencias Humanas y Sociales de H. G. Gadaner. PPU. Barcelona, 1994. Gadamer, llans-Georg: Verdad y método. Sigueme, Salamanca, 1991. 
conocimiento (Sociología del Conocimiento) ${ }^{2}$ y la racionalidad se descubre como interesada (Ravvls). ${ }^{3}$ La continua erosión a que se ve sometida la razón moderna, la conduce, finalmente, a una situación de pleno alienamiento : queda prisionera de la "performatividad", de la operatividad práctica y ocasional, en el pensamiento posmoderno. ${ }^{4}$

Un desarrollo y ejercico correcto de una razón gestora, de una razón que corrija los excesos e insuficiencias de la razón rectora, entronizada a partir de Descartes, exige insertarse en el marco histórico-social, ser inlerente a la propia acción par a sacar el máximo provecho a los condicionamientos que posea, y sufrir continuos procesos de retroalimentación en su intento de dirigir el proceso desde dentro, acomodándose a su naturaleza y posibilidades para alcanzar con éxito el fin que inspira la acción, la dirige y la trasciende. No escindirá, en consecuencia, al hombre en mente y cuerpo; abandonará las "metáforas visuales y en especial la del espejo", 6 que han conformado la epistemologia tradicional, para insertarse en planteamientos hermenéuticos y buscar el consenso de la comunidad cientifica, o sea, la "objetividad intersubjetiva", como parámetro cientifico; recuperará la dimensión ética y axiológica, no sólo por estar la acción ennoblecida por una racionalidad no interesada, sino también por encontrarse trascendida por una visión de futuro y dentro de una perspectiva de globalidad, y consecuentemente fermentada, en su dinámica interna, por la tensión entre la situación de hecho y la de derecho. Esta tensión hará posible el progreso. Un progreso revelado no como metarrelato o condicionamiento normativo externo, sino como algo inherente al propio proceso perfectivo y humanizador de la acción o del curso social.

2 Lamo de Espinosa, E. y otros: La sociologia del conocimiento y de la ciencia. Alianza Universidad. Madrid, 1994.

3 Rawls, John: Teoria de la Justicia. FCE, Mexico, 1979.

4 Vattimo, Gianni: Las orenturas de la diferencia. Peninsula. Barcelona, 1990. Lyotard, Jean Franáois: La diferencia. Gedisa. Barcelona, 1988.

5 Bodei, Remo: Una geometria de las pasiones. Muchuik. Barcelona, 1995.

6 Rorty, Richard: La Filosofia y el espejo de la Naturaleza. Cátedra. Madrid, 1989. 